\title{
Multiplex bacterial polymerase chain reaction in a cohort of patients with pleural effusion
}

\author{
Léo Franchetti, Desiree M. Schumann", Michael Tamm, Kathleen Jahn and Daiana Stolz
}

\begin{abstract}
Background: The identification of the pathogens in pleural effusion has mainly relied on conventional bacterial culture or single species polymerase chain reaction (PCR), both with relatively low sensitivity. We investigated the efficacy of a commercially available multiplex bacterial PCR assay developed for pneumonia to identify the pathogens involved in pleural infection, particularly empyema.

Methods: A prospective, monocentric, observational study including 194 patients with pleural effusion. Patients were evaluated based on imaging, laboratory values, pleura ultrasound and results of thoracentesis including conventional microbiology studies during hospitalisation. Multiplex bacterial PCR (Curetis Unyvero p55) was performed in batch and had no influence on therapeutic decisions.

Results: Overall, there were 51/197 cases with transudate and 146/197 with exudate. In 42\% ( $n=90 / 214)$ there was a clinical suspicion of parapneumonic effusion and the final clinical diagnosis of empyema was made in $29 \%$ ( $n=$ 61/214) of all cases. The most common microorganisms identified in the cases diagnosed with empyema were anaerobes [31] followed by gram-positive cocci [10] and gram-negative rods [4]. The multiplex PCR assay identified more of the pathogens on the panel than the conventional methods $(23.3 \%(7 / 30)$ vs. $6.7 \%(2 / 30), p=0.008)$.

Conclusion: The multiplex PCR-based assay had a higher sensitivity and specificity than conventional microbiology when only the pathogens on the pneumonia panel were taken into account. A dedicated pleural empyema multiplex PCR panel including anaerobes would be needed to cover most common pathogens involved in pleural infection.
\end{abstract}

Keywords: Multiplex PCR, Pleural empyema, Bacteria, Pathogen, Para-pneumonic effusion

\section{Background}

Microbial diagnosis and the identification of the pathogens causing pleural infection have generally relied on conventional bacterial culture [1]. Due to the increase in the complexity of the pathogens and the increased use of antibiotic pre-treatment, the sensitivity of the conventional bacterial culture has decreased [2, 3]. Also, culture of pleural fluid is difficult, particularly with the use of broad-spectrum antibiotics, which can hinder bacterial growth. The highest yield of $60 \%$ can be achieved with inoculation in standard blood culture bottles [4]. The high rate of culture-negative samples thus complicates

\footnotetext{
* Correspondence: desiree.schumann@usb.ch

Clinic of Pulmonary Medicine and Pulmonary Cell Research, University Hospital Basel, Petersgraben 4, 4031 Basel, CH, Switzerland
}

clinical care and often precludes streamlining to selective antibiotics.

With the advancement in technology, molecular techniques have been implemented for accurate pathogen identification in diagnostic microbiology. Broad-range $16 \mathrm{~S}$ rRNA gene polymerase chain reaction (PCR) is often used to detect and identify all bacterial pathogens in primary sterile clinical specimens, mostly in cases where bacterial infection is suspected, but where cultures are negative. PCR using broad-range $16 \mathrm{~S}$ rRNA gene primers has been used to determine the aetiology of pleural empyema and offers a relatively high detection rate of up to $85 \%$ in a single assay, allowing the rapid introduction of targeted antibiotic therapy $[3,5-7]$. In previous studies, multiplex PCR methods in different matrices (blood, sputum,

(c) The Author(s). 2020 Open Access This article is distributed under the terms of the Creative Commons Attribution 4.0 International License (http://creativecommons.org/licenses/by/4.0/), which permits unrestricted use, distribution, and 
throat or nasopharyngeal swabs) have proven to be useful in diagnosing respiratory tract infections and decreasing the financial costs [8]. They have also shown a better sensitivity $[9,10]$, especially in children $[11,12]$. They also seem to be effective for reducing the incidence of empyema [12]. However, some studies have shown limitations to the sensitivity of the PCR [13].

Whether a multiplex bacterial PCR focusing on pathogens commonly encountered in pneumonia improves the diagnosis and management of patients with pleural effusion remains unexplored. Thus, the objective of this study was to investigate the diagnostic performance of a commercially available multiplex bacterial PCR-based assay in the pleural fluid of patients with pleura effusion. We hypothesize that the molecular diagnostic technique improves the diagnostic yield of conventional culture for the detection of pathogens in pleural effusion.

\section{Methods}

This was a prospective, non-interventional study conducted in the University Hospital Basel, Switzerland. This study was conducted in accordance with the amended Declaration of Helsinki. An independent ethics committee, Ethikkommission Beider Basel, approved the study (EKBB 120/ $10)$ and the subjects provided written informed consent.

\section{Study design}

All hospitalized adult patients with pleural effusion referred to the Clinic of Pneumology at the University Hospital Basel, Switzerland during a period of 48 months were considered for the study. Inclusion criteria were: a) age > 18 years; b) more than "minimal" pleural effusion, i.e. an effusion requiring diagnostic or therapeutic procedure; c) informed consent signed by the patient. The first pleural effusion sampling was used for analysis in cases where pleural effusion sampling from the same patient occurred more than once during a single hospital visit. Immunosuppression was defined as manifested AIDS, chemotherapy, status after solid organ transplantation, status after haematological stem cell transplantation, progressive uncontrolled malignancy or neutropenia $\left(<500^{*} 10^{9} / \mathrm{L}\right)$.

\section{Diagnostic work-up}

Pleural effusion specimens were collected and examined routinely. Gram and other appropriate stains and cultures for bacteria, mycobacteria, and fungi were performed according to standard procedures [14]. Cell differentiation in the pleural fluid was reported as absolute numbers and as a percentage of the total cell count.

\section{Conventional methods}

Forty microliters of vortexed pleural fluid were added to culture plates including Columbia sheep blood agar, Colistin Nalidixic Acid blood agar for Gram positive bacteria,
Haemophilus chocolate agar and MacConkey for Gram negatives [14]. These plates were incubated for 2 days at $36^{\circ} \mathrm{C}$. In the case of additional investigations such as for the Legionella spp. or moulds, specific selective plates for these pathogens were inoculated additionally. The incubation times and conditions varied according to specific pathogens. Isolates were identified by matrix-assisted laser desorption/ ionization-time-of-flight (MALDI-TOF), mass spectrometry (MALDI BioTyper, Bruker Daltonics, Bremen, Germany), biochemical profiling or $16 \mathrm{~S}$ rDNA sequencing.

All samples were cultured at the time of hospitalisation and used for the diagnoses.

\section{Curetis Unyvero PHN assay}

Molecular analysis of pleural fluid was performed in batch on stored samples using the multiplex PCR-based assay testing system from Curetis AG (Holzgerlingen, Germany), according to the manufacturers' instructions. This assay panel targets specific genes for the following 20 bacteria: Staphylococcus aureus, Streptococcus pneumoniae, Enterobacteriaceae, Citrobacter freundii, Escherichia coli, Enterobacter cloacae complex, Enterobacter aerogenes, Proteus spp., Klebsiella pneumoniae, Klebsiella oxytoca, Klebsiella variicola, Serratia marcescens, Morganella morganii, Moraxella catarrhalis, Pseudomonas aeruginosa, Acinetobacter baumannii complex, Stenotrophomonas maltophilia, Legionella pneumophila, Haemophilus influenza, Mycoplasma pneumoniae and one fungus: Pneumocystis jirovecii. It is also able to recognize 22 genetic markers of resistance including $\beta$-lactam, macrolide, fluoroquinolone and Carbapenem resistance.

Time estimated for sample preparation, DNA extraction and purification, amplification and specific detection is approximately $4 \mathrm{~h}$. Operators of the assay and all other microbiological methods were unaware of the results and did not participate in any data analysis.

Results of the commercial multiplex PCR did not impact patient management. The samples were stored at $20{ }^{\circ} \mathrm{C}$ immediately after extraction from the body. The samples were then thawed at $4{ }^{\circ} \mathrm{C}$ for approximately $3 \mathrm{~h}$ after which it was aliquoted and subsequently stored at $-80^{\circ} \mathrm{C}$

\section{Diagnostic criteria and data collection}

Data were collected at the time of pleural fluid sampling and included demographics, comorbidities, laboratory findings, radiologic results, medication history, final diagnosis (based on all available clinical and laboratory results) and clinical outcome. Samples were dichotomized in transudate and exudate according to the Light criteria [15, 16]. Empyema was defined as a positive Gram stain or bacterial culture, the presence of pus (macroscopic purulence) in the pleural space or pleural fluid $\mathrm{pH}<7.2$ with clinical evidence of infection [17]. 


\section{Statistical analysis}

Numerical results were expressed as mean (standard deviation) or median (interquartile range) unless otherwise stated. Differences in dichotomous variables were evaluated using the Chi-square test. All other continuously non-normally distributed parameters were evaluated using the non-parametric Mann-Whitney U test. Reference standards used to calculate the diagnostic yield (sensitivity and specificity) of the bacterial multiplex PCR analyses were threefold: conventional culture, clinical diagnosis of empyema as described by the attending physician in the final hospitalisation report and pleural effusion $\mathrm{pH} \leq 7.2$. A $p$-value of $<0.05$ was considered significant. No imputation was made when data were missing. Data analyses were conducted according to the Statistical Package for Social Sciences (SPSS, version 22 for Windows) program.

\section{Results}

A total of 194 patients with 214 visits were included in the study (Fig. 1). More than half of the participants were male and the average age was $68.8 \pm 15.5$ years (Table 1). Twenty-two percent of the patients were current smokers and the most common symptom at admission was cough. The 30 -day mortality was $9.8 \%(n=$ $19 / 194)$ and the 90 -day mortality was $13.9 \%(n=27 /$ 194). The most prevalent antibiotic class was penicillins (93/128) followed by cephalosporins (34/128) and carbapenems (20/128). Antibiotics with anaerobic coverage were given as treatment to $105 / 128$ cases. All patients underwent imaging studies with a thoracic ultrasound performed in nearly $90 \%$ of the cases. Various radiological investigations were performed to diagnose the patient (Table 2).

There were 51/197 (26\%) samples classified as transudate and 146/197 (74\%) were classified as exudate. Among the exudates, $18 / 146$ (12\%) samples were positive for pathogens when using conventional methods compared to 13/
$146(8.9 \%)$ positive samples when using the multiplex PCR-based assay (Curetis Unyvero P55 assay). Three of the pathogens identified using conventional methods were on the Curetis Unyvero P55 panel (Table 3).

When only taking into account the 21 pathogens included in the Curetis Unyvero P55 panel, more samples were positive for pathogens using the multiplex PCRbased assay $(n=15 / 214)$ compared to conventional methods $(n=3 / 214, p<0.001$, Table 3$)$. The sensitivity of the multiplex PCR-based assay was $67 \%$ and specificity was $94 \%$ when using the conventional method as a reference. (Table 4). When considering all pathogens, i.e. also pathogens not included in the panel, the sensitivity of the multiplex PCR-based assay decreased (Table 4).

There was a suspicion of empyema based on the ultrasound findings in 35/189 (18.5\%) cases and from those, 30 cases (85.7\%) were diagnosed with empyema (16 hospital-acquired and 14 community-acquired pneumonia). Of all the cases with suspicion of empyema, 47/79 (22.0\%) were diagnosed with empyema and, of the cases with no suspicion of empyema at admission, 14/135 (10.4\%) had a final diagnosis of empyema. In total, 29\% ( $n=61 / 214)$ of the cases had a final clinical diagnosis of empyema. The cases with empyema were significantly younger, with lower blood lactate dehydrogenase values but higher pleural fluid lactate dehydrogenase levels, longer antibiotic treatment before sampling and longer hospital stays compared to cases without empyema (Table 5). As expected, pleural fluid $\mathrm{pH}$ and glucose were significantly lower in cases with empyema compared to cases without empyema. There was no association between mortality (Exp $\beta=1.394,95 \%$ CI $0.551-3.530$; $p=0.483$ ) or immune status (Exp $\beta=0.676,95 \%$ CI $0.300-1.519 ; p=0.343$ ) and the empyema diagnosis.

When using final clinical diagnosis of empyema as the reference-standard, the multiplex PCR-based assay had a lower sensitivity but slightly higher specificity than conventional methods (Table 4). However, when restricting

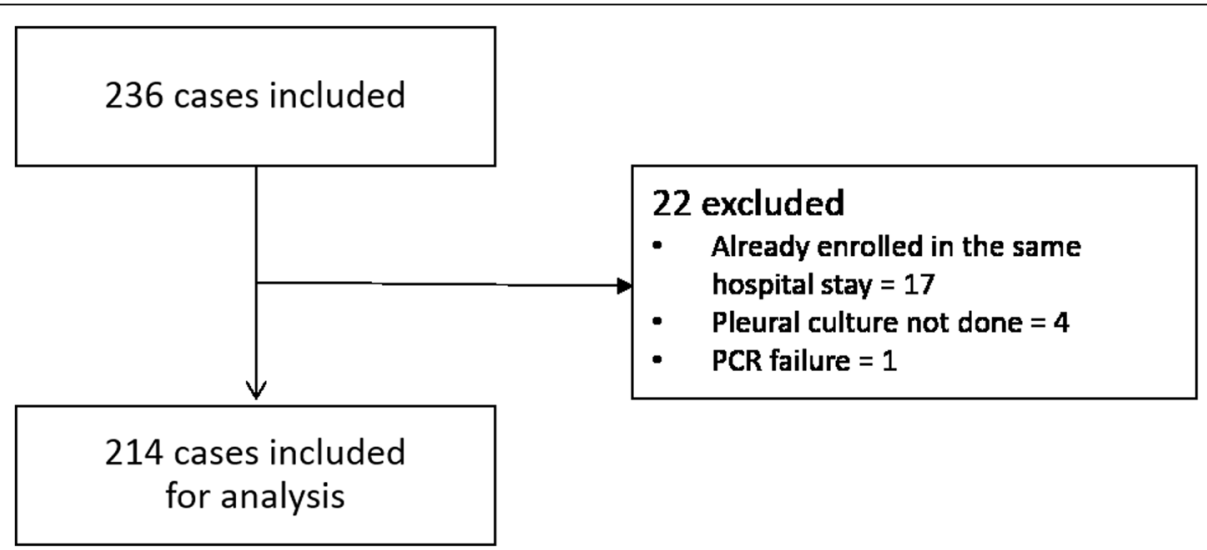

Fig. 1 Flow chart depicting patient cohort selection criteria 
Table 1 Basic characteristics of the study participants with pleural effusion, $n=194$; cases $=214$

\begin{tabular}{|c|c|c|}
\hline & $N=194$ & Missing data \\
\hline Age, y & $68.8 \pm 15.5$ & 0 \\
\hline Male & $112(58)$ & 0 \\
\hline unadjusted Charlson Score & $4.8 \pm 2.7$ & 0 \\
\hline ASA Score & $3.1 \pm 0.44$ & 0 \\
\hline Length of hospital stay, days & $16.0(7.0 ; 27.5)$ & 0 \\
\hline Smoking status & & 10 \\
\hline Current smoker & $42(22)$ & \\
\hline Non-smoker & $61(31)$ & \\
\hline \multicolumn{3}{|l|}{ Immune status } \\
\hline Immunosuppressed & $40(18.6)$ & 1 \\
\hline Signs and symptoms & & 2 \\
\hline Cough & $91(43)$ & \\
\hline Sputum & $56(26)$ & \\
\hline Fever & $58(27)$ & \\
\hline Chest pain & $53(25)$ & \\
\hline \multicolumn{3}{|l|}{ Blood parameters } \\
\hline Performed & $206(96)$ & 8 \\
\hline Leucocytes $\left({ }^{*} 10^{9} / \mathrm{l}\right)$ & $10.4 \pm 7.6$ & 0 \\
\hline Neutrophils $\left({ }^{*} 10^{9} / \mathrm{l}\right)$ & $7.9 \pm 5.5$ & 32 \\
\hline C-reactive protein (mg/l) & $118.1 \pm 109.8$ & 3 \\
\hline Lactate dehydrogenase (U/I) & $287.4 \pm 208.9$ & 6 \\
\hline \multicolumn{3}{|l|}{ Pleural fluid parameters } \\
\hline Performed & $214(100)$ & \\
\hline Transudate & $51(26)$ & 7 \\
\hline Exudate & $146(74)$ & 7 \\
\hline Protein $(\mathrm{g} / \mathrm{l})$ & $34.2 \pm 11.6$ & 7 \\
\hline Glucose (mmol/l) & $5.6 \pm 2.9$ & 26 \\
\hline $\mathrm{pH}$ & $7.3 \pm 0.23$ & 35 \\
\hline $\mathrm{pH} \leq 7.2$ & $37(21)$ & 35 \\
\hline Lactate dehydrogenase (U/I) & $1047.9 \pm 3895.3$ & 20 \\
\hline Anti-infective therapy before sampling & $130(61)$ & 0 \\
\hline Antibiotics & $128(60)$ & 0 \\
\hline Anti-fungal & $11(5)$ & 0 \\
\hline Anti-viral & $10(5)$ & 0 \\
\hline \multicolumn{3}{|l|}{ Duration of antibiotic therapy } \\
\hline Before sampling & $1[0 ; 7]$ & 1 \\
\hline After sampling & $8[0 ; 21]$ & 0 \\
\hline Total & $14[0 ; 34]$ & 1 \\
\hline \multicolumn{3}{|l|}{ Final clinical diagnosis } \\
\hline Empyema & $61(29)$ & 0 \\
\hline \multicolumn{3}{|l|}{ Therapeutic regime } \\
\hline Conservative & $175(82)$ & 0 \\
\hline Operative & $39(18)$ & 0 \\
\hline Drainage & $158(74)$ & 0 \\
\hline
\end{tabular}


Table 1 Basic characteristics of the study participants with pleural effusion, $n=194$; cases $=214$ (Continued)

\begin{tabular}{lll}
\hline & $N=194$ & Missing data \\
\hline Medical Thoracoscopy & $83(39)$ & 0 \\
Outcomes & & $18(9.3)$ \\
In-house mortality within 30 days of sampling & $68(35)$ & 0 \\
Re-hospitalisation within 90 days of discharge & $57(27)$ & 0 \\
Operation within 60 days of sampling &
\end{tabular}

Median (IQR) or mean (standard deviation), $\mathrm{n}(\%)$

the analyses to the 21 pathogens available on the panel, the sensitivity of the conventional methods decreased to $3.3 \%$.

Four samples positive for pathogens (Stenotrophomonas maltophilia, Citrobacter freundii, Pseudomonas aeruginosa and Proteus spp.) using the multiplex PCR and six samples positive for pathogens (Staphylococcus capitis, Staphylococcus hominis, Mycobacterium avium, Enterobacter cloacae,

Table 2 Radiological investigations of the patients included in the study

\begin{tabular}{ll}
\hline & Patient number =194; cases $=214$ \\
\hline X-Ray results & $128(60)$ \\
Performed & $126(98)$ \\
Effusion & $62(48)$ \\
Meniscus & $39(30)$ \\
Infiltrate & $4(3)$ \\
Suspicion of empyema & \\
CT-scan findings & $139(65)$ \\
Performed & $139(100)$ \\
Effusion & $52(37)$ \\
Infiltrate & $49(35)$ \\
Nodule/Tumor & $20(14)$ \\
Enhancement & $18(13)$ \\
Suspicion of empyema & \\
Ultrasound findings & $189(88)$ \\
Performed & $19(10)$ \\
Hyperechogenicity & $42(22)$ \\
Septa & $35(19)$ \\
Massive organisation & $73(34)$ \\
single category & $24(33)$ \\
Macroscopic bronchoscopy findings & \\
Performed & $73(34)$ \\
No pathological finding & \\
Non-purulent secretion & \\
Erythema of the mucosa & \\
Purulent secretion & $(23)$ \\
\hline
\end{tabular}

Campylobacter concisus, Veillonella spp., Propionibacterium acnes and Micrococcus luteus) using conventional methods were considered to be negative for empyema in the final clinical diagnosis.

The most common microorganisms identified by conventional methods and the multiplex PCR assay in the cases diagnosed with empyema were anaerobes $(31 / 45)$ followed by gram-positive cocci (10/45) and gram-negative rods (4/45). About one third of all the cases $(n=9 / 26,35 \%)$ proved to be multi-bacterial when using conventional methods (Table 6).

In the cases with a final diagnosis of empyema, there was a significant association between antibiotic therapy before sampling and conventional culture results with a $10.5 \mathrm{x}$ increase in the odds of a negative culture result $[\operatorname{Exp}(B)=10.5,95 \%$ CI 1.933-57.029; $p=0.006]$. Also between duration of antibiotic therapy before sampling $[\operatorname{Exp}(B)=0.877$ 95\% CI 0.774-0.993; $p=0.039]$ and conventional culture results. There was no association between antibiotic therapy before sampling $(\operatorname{Exp}(\mathrm{B})=$ 1.556, 95\% CI 0.269-8.995; $p=0.622$ ), the duration of antibiotic therapy before sampling $(\operatorname{Exp}(B)=1.008,95 \%$ CI $0.931-1.092 ; p=0.836$ ) and the multiplex PCR assay result.

\section{Discussion}

Pleural infection is a common complication in pneumonia and linked with high mortality [18, 19]. Early and reliable detection of the causative organism is beneficial in establishing the correct pathogen-specific treatment, which may lead to decreased morbidity and mortality. However, due to the low sensitivity of conventional cultures [1], the diagnosis and management of pleural infection remains challenging $[2,3]$.

In this study we assessed the diagnostic accuracy of a commercial multiplex bacterial PCR for the detection of pathogens in pleural effusion compared with conventional methods in a large group of patients with pleural effusion. We found that the multiplex PCR had a better sensitivity and specificity than conventional methods if the analysis is restricted to microorganisms included on the panel. Indeed, when using the clinical final diagnosis of empyema as a reference, the multiplex PCR-based assay had sensitivity six-times higher than that of the 
Table 3 Pathogens and how often the pathogens were identified using conventional methods compared to the multiplex PCRbased assay

\begin{tabular}{|c|c|c|c|}
\hline Pathogen & Conventional method positive & Multiplex PCR-based assay positive & \\
\hline Citrobacter freundii & & 1 & Gram-negative \\
\hline Enterobacter cloacae & 1 & & Gram-negative \\
\hline Proteus spp. & & 1 & Gram-negative \\
\hline Pseudomonas aeruginosa & & 1 & Gram-negative \\
\hline Staphylococcus aureus & 1 & 2 & Gram-positive \\
\hline Stenotrophomonas maltophilia & & 5 & Gram-negative \\
\hline Streptococcus pneumoniae & 1 & 5 & Gram-positive \\
\hline \multicolumn{4}{|c|}{ Pathogens not on the Curetis p55 panel } \\
\hline Bacteroides fragilis & 1 & & Anaerobic \\
\hline Campylobacter species & 2 & & Anaerobic \\
\hline Eikenella corrodens & 2 & & Anaerobic \\
\hline Enterococcus faecium & 1 & & Gram-positive \\
\hline Finereferenceia magna & 1 & & Anaerobic \\
\hline Fusobacterium nucleatum & 4 & & Anaerobic \\
\hline Lactobacillus & 1 & & Anaerobic \\
\hline Micrococcus luteus & 1 & & Gram-positive \\
\hline Mycobacterium avium & 1 & & Gram-positive \\
\hline Parvimonas micra & 2 & & Anaerobic \\
\hline Prevotella species & 4 & & Anaerobic \\
\hline Propionibacterium acnes & 1 & & Anaerobic \\
\hline Staphylococcus capitis & 1 & & Gram-positive \\
\hline Staphylococcus hominis & 1 & & Gram-positive \\
\hline Streptococcus agalactiae & 1 & & Gram-positive \\
\hline Streptococcus anginosus & 5 & & Anaerobic \\
\hline Streptococcus constellatus & 1 & & Anaerobic \\
\hline Streptococcus intermedius & 2 & & Anaerobic \\
\hline Streptococcus milleri & 4 & & Anaerobic \\
\hline Streptococcus mitis & 1 & & Anaerobic \\
\hline Streptococcus sanguinis & 1 & & Anaerobic \\
\hline Veillonella species & 1 & & Anaerobic \\
\hline
\end{tabular}

conventional microbiologic methods. However, only a minority of the samples and a small percentage of the pathogens diagnosed by conventional methods were included in this panel including bacteria commonly involved in pneumonia. Considering that empyema is a common complication of pneumonia, it would be reasonable to suggest that the pathogens involved in empyema are similar to those found in pneumonia. Based on pathogens identified for pleural fluid in various other publications $[2,3,5,6,13,20-22]$, at least $50 \%$ of the known pathogens were available on the multiplex PCRbased assay. Yet, only 7 (24\%) of the 29 pathogens identified by either conventional or molecular methods in this study were included on the panel of this multiplex bacterial PCR for pneumonia.
Most of the pathogens detected in the patients diagnosed with empyema were anaerobes (69\%) followed by gram-positive cocci (22\%). These figures were unexpected and differ from previous reports suggesting that organisms related to community-acquired pneumonia, such as $S$. pneumonia, $H$. influenza, S. aureus, K.Pneumoniae, are the most common causes of empyema [2, 3, 5, 13, 20, 23]. A more recent paper by Johansson et al. [24], however, had similar results to our study, in that they found an anaerobe presence of $40 \%$. Thus, empyema might require anaerobe coverage more often than commonly reported.

Streptococcus pneumoniae, the most common pathogen causing parapneumonic effusions [2, 3, 10, 25] was identified in 5 samples using the multiplex PCR-based assay and only once when using conventional methods. 
Table 4 Diagnostic performance of conventional methods and the multiplex PCR-based assay and using conventional methods, final clinical diagnosis of empyema, empyema and pleura fluid $\leq 7.2$ as reference-standard

\begin{tabular}{|c|c|c|c|}
\hline 1. All cases - Conventional methods as reference-standard & Sensitivity (\%) & Specificity (\%) & Positive predictive value (\%) \\
\hline Multiplex PCR-based assay vs. all pathogens & 12 & 93.5 & 20 \\
\hline Multiplex PCR-based assay vs. only panel pathogens & 67 & 93.7 & 13 \\
\hline $\begin{array}{l}\text { 2. Using cases with final clinical diagnosis of empyema - } \\
\text { conventional methods as reference-standard }\end{array}$ & Sensitivity & Specificity & \\
\hline Multiplex PCR-based assay vs. all pathogens & 15.8 & 80 & 27 \\
\hline Multiplex PCR-based assay vs. only panel pathogens & 100 & 84.2 & 18 \\
\hline $\begin{array}{l}\text { 3. Using cases with or without empyema diagnosis as } \\
\text { reference-standard }\end{array}$ & Sensitivity & Specificity & \\
\hline Conventional methods (all pathogens) & 32.8 & 96.1 & 77 \\
\hline Conventional methods only panel pathogens & 3.3 & 99.3 & 67 \\
\hline Multiplex PCR-based assay & 18.6 & 97.3 & 73 \\
\hline $\begin{array}{l}\text { 4. Using cases with or without pleural fluid } \mathrm{pH} \leq 7.2 \text { as } \\
\text { reference standard }\end{array}$ & Sensitivity & Specificity & \\
\hline Conventional methods (all pathogens) & 37.8 & 95.8 & 70 \\
\hline Conventional methods only panel pathogens & 2.7 & 99.3 & 100 \\
\hline Multiplex PCR-based assay & 13.5 & 97.1 & 56 \\
\hline
\end{tabular}

Table 5 Patients with a diagnosis of no empyema compared to patients with a final diagnosis of empyema

\begin{tabular}{|c|c|c|c|}
\hline & No Empyema & Empyema & $p$-value \\
\hline Age, y & $70.4 \pm 15.4$ & $65.0 \pm 15.2$ & 0.012 \\
\hline Length of stay, days & $13(4.0 ; 22.0)$ & $25.0(15.0 ; 35.5)$ & $<0.001$ \\
\hline unadjusted Charlson score & $4.9 \pm 2.6$ & $4.7 \pm 3.1$ & 0.572 \\
\hline ASA score & $3.1 \pm 0.46$ & $3.0 \pm 0.4$ & 0.668 \\
\hline Smoking status & & & 0.006 \\
\hline Current smoker & $25(17)$ & $23(38)$ & \\
\hline Non-smoker & $49(34)$ & $16(27)$ & \\
\hline \multicolumn{4}{|l|}{ Blood parameters } \\
\hline Leucocytes $\left({ }^{*} 10^{9} / \mathrm{l}\right)$ & $9.2 \pm 7.4$ & $13.3 \pm 7.1$ & $<0.001$ \\
\hline Neutrophils $\left({ }^{*} 10^{9} / \mathrm{l}\right)$ & $6.2 \pm 3.5$ & $11.3 \pm 7.1$ & $<0.001$ \\
\hline C-reactive protein (mg/l) & $81.3 \pm 83.4$ & $203.7 \pm 116.6$ & $<0.001$ \\
\hline Lactate dehydrogenase (U/I) & $315.8 \pm 229.4$ & $222.8 \pm 132.6$ & $<0.001$ \\
\hline \multicolumn{4}{|l|}{ Pleural fluid parameters } \\
\hline Protein (g/l) & $33.6 \pm 11.3$ & $36.1 \pm 12.2$ & 0.074 \\
\hline Glucose (mmol/l) & $6.1 \pm 2.7$ & $4.3 \pm 3.2$ & $<0.001$ \\
\hline $\mathrm{pH}$ & $7.4 \pm 0.11$ & $7.1 \pm 0.3$ & $<0.001$ \\
\hline LDH (U/l) & $439.5 \pm 637.5$ & $3339.3 \pm 7558.9$ & $<0.001$ \\
\hline \multicolumn{4}{|l|}{ Antibiotic duration (days) } \\
\hline Before sampling & $0(0 ; 6)$ & $4.0(1.0 ; 9.0)$ & $<0.001$ \\
\hline After sampling & $5.0(0 ; 10)$ & $26.0(15.5 ; 37.5)$ & $<0.001$ \\
\hline Total antibiotic treatment & $7.0(0 ; 15)$ & $31.0(20 ; 44)$ & $<0.001$ \\
\hline \multicolumn{4}{|l|}{ Patient outcome } \\
\hline 30-day mortality & $12(9)$ & $7(12)$ & 0.598 \\
\hline
\end{tabular}


Table 6 Pathogens identified in multi-bacterial samples

\begin{tabular}{ll}
\hline & Pathogens \\
\hline Sample 1 & Streptococcus anginosus, Prevotella spp., Parvimonas micra \\
Sample 2 & Lactobacillus, Streptococcus intermedius \\
Sample 3 & $\begin{array}{l}\text { Streptococcus constellatus, Parvimonas micra, Prevotella spp., } \\
\text { Campylobacter spp., Fusobacterium spp. }\end{array}$ \\
Sample 4 & Streptococcus milleri, Eikenella corrodens \\
Sample 5 & Eikenella corrodens, Fusobacterium spp., Prevotella oris \\
Sample 6 & Campylobacter concisus, Veillonella spp. \\
Sample 7 & Staphylococcus capitis, Staphylococcus hominis \\
Sample 8 & Streptococcus agalactiae, Streptococcus anginosus, \\
& Finereferenceia magna, Prevotella spp., Fusobacterium spp. \\
Sample 9 & Streptococcus milleri, Fusobacterium nucleatum \\
\hline
\end{tabular}

Conventional methods identified only one Stenotrophomonas maltophilia sample compared to the multiplex PCR-based assay that identified it in five samples. Although Stenotrophomonas maltophilia is a gram-negative pathogen known to cause many severe infections and can result in mortality in approximately 14.6 to $42.5 \%$ of patients [26-28], pleural infection associated with this organism is rare [28]. Stenotrophomonas maltophilia is thought to cause nosocomial infections mainly in immunocompromised patients [28], but in our study, only one patient identified with this pathogen was immunocompromised and four of the five cases positive for Stenotrophomonas maltophilia had a final diagnosis of empyema. It is plausible that the molecular diagnostic technique could improve the recognition of this pathogen, which is associated with a particularly high mortality rate.

In $85 \%(52 / 61)$ of the cases diagnosed with empyema, antibiotics had been administered before sampling. As found previously [29], we found no association between the multiplex PCR-based assay and prior administration of antibiotics or duration of antibiotic use before sampling in the cases diagnosed with empyema. However, antibiotic use before sampling and the duration of antibiotic use before sampling was associated with more bacterial negative results when using the conventional method in the cases diagnosed with empyema.

When using the final clinical diagnosis of empyema (yes or no) as reference-standard, the multiplex PCRbased assay had a sensitivity of $18.6 \%$ and a specificity of 97.3\%. When restricting the analysis to pathogens included in the panel, conventional methods had a sensitivity of 3.3\%. Twenty-two pathogens were detected by conventional methods and were not on the multiplex PCR panel and when these pathogens were included in the analysis, conventional methods had a sensitivity of $32.8 \%$.

The diagnostic accuracy of this multiplex bacterial panel focusing on pneumonia pathogens for pleural effusion was disappointingly low and highlighted the fact that before introduction in clinical practice, any diagnostic approach should be evaluated in a clinical study. It was apparent that a dedicated panel including anaerobes would be necessary to increase the diagnostic yield of a molecular technique aimed at diagnosing pleural infection.

In this study, we evaluated the diagnostic yield of conventional culture and a molecular technique in pleural effusions in a well-characterized, considerable sized cohort of patients. It is important to take into consideration that a bacterial multiplex PCR is limited its diagnostic yield due to the finite number of in-panel organisms. In addition, specificity issues regarding Enterobacter spp., $H$. influenzae and S. pneumoniae in comparison to culturebased methods have been previously reported for the molecular diagnostic test prototype [30]. Unlike others [30] with relevant technical failure rates when analysing respiratory secretions, the multiplex PCR assay had a 2.3\% $(5 / 214)$ failure rate in the current study when analysing pleural fluid.

Amongst its limitations, one has to underline the fact that the molecular diagnostics were performed on frozen material which may have affected the outcome of the analysis. Fernández-Soto $\mathrm{P}$ et al. found that less deoxyribonucleic acid (DNA) is extracted from urine frozen and stored for an extended time period compared to fresh urine [31]. Cushwa and Medrano found differences in DNA extraction from blood, based on length of storage time and storage temperature [32]. Thus, the sensitivity of the method may have been negatively impacted by the storage of the samples. However, the main obstacle for the detection of the pathogens by the PCR was the fact that they were not included in the spectrum of the panel for pneumonia. Thus, an increase in DNA amount was not expected to positively increase the sensitivity of the assay. Further, we had not used any further method to confirm the presence or absence of bacteria in the pleural effusion. This was a natural limitation as currently no diagnostic technique would be able to identify infection in this setting [33]. Nevertheless, the clinical final diagnosis had been additionally used as a referencestandard to identify infection. Recently, next-generation sequencing (NGS) was used to identify pathogens in empyema and 385 bacterial detections were made, compared to 38 by culture and 87 by $16 \mathrm{~S}$ rRNA gene sequencing [34]. The authors concluded that a subgroup of patients with empyema have pathogens more resembling a brain abscess than pneumonia, ie. anaerobic pathogens and that this subgroup should be seen as primary empyema. With this new technique many more bacterial detections were made, but the conclusion that anaerobes are important in empyema remains the same as the conclusion we have drawn in our study. It would be interesting to compare sensitivity and specificity as well as cost-effectiveness between a multiplex PCR-based assay and NGS. 
We were unable to determine the clinical implications of the commercial multiplex PCR-based assay on the treatment and outcome of the patients. Thus, further studies are necessary to evaluate whether a molecular diagnostic technique can be helpful in optimizing treatment of pleural infections. We believe that our results are generalizable, in that anaerobes may be important in empyema, but the exact species may differ between regions.

\section{Conclusion}

In conclusion, most causative organisms were not included in the pneumonia panel. Thus, a dedicated pleural empyema multiplex PCR including anaerobes is required in pleural infection. The multiplex bacterial PCR assay had a higher sensitivity and specificity than conventional microbiology to diagnose bacterial infection in pleural effusion when only pathogens included on the panel were taken into account.

\section{Abbreviations}

DNA: Deoxyribonucleic acid; IQR: Interquartile range; PCR: Polymerase chain reaction; rRNA: Ribosomal ribonucleic acid; spp.: Species

\section{Acknowledgments}

This work was presented as a poster presentation at the Schweizerische Gesellschaft für Pneumologie (SGP) annual conference in St. Gallen, Switzerland, 24-25 May 2018 [35]. This work was also presented as an oral presentation at the European Respiratory Society Annual Conference in Paris, France 15 - 19 September 2018.

\section{Authors' contributions}

Data collection, accuracy of data, contributed to discussion of results, statistical analysis, writing of the manuscript, finalization of the manuscript, and approval of the submitted article: LF, DMS, KJ, TM. Conceived the research project, contributed in clinical work, integrity and accuracy of data, preparing, and approval of the submitted article: DS. All authors have read and approved the manuscript.

\section{Funding}

Daiana Stolz was supported by grants from the Swiss National Foundation (PP00P3_128412/1). The Swiss National Foundation had no influence on the design of the study, the collection, analysis and interpretation of data nor on the writing of the manuscript.

\section{Availability of data and materials}

The datasets used and/or analysed during the current study are available from the corresponding author on reasonable request.

\section{Ethics approval and consent to participate}

An independent ethics committee, Ethikkommission Beider Basel, approved the study (EKBB 120/10) and the subjects provided written informed consent.

\section{Consent for publication}

\section{Not applicable}

\section{Competing interests}

The authors declare that they have no competing interests. The Curetis Unyvero P55 assay cartridges were donated by Curetis AG, Holzgerlingen, Germany. The sponsors of this investigator-initiated project had no involvement in the design and conduct of the study, collection, management, analysis, and interpretation of the data, nor in the preparation, review, and approval of the manuscript or decision to submit the manuscript.
Received: 14 May 2019 Accepted: 14 January 2020

Published online: 01 February 2020

\section{References}

1. Lasken RS, McLean JS. Recent advances in genomic DNA sequencing of microbial species from single cells. Nat Rev Genet. 2014;15(9):577-84.

2. Le Monnier A, Carbonnelle E, Zahar J-R, Le Bourgeois M, Abachin E, Quesne $\mathrm{G}$, et al. Microbiological diagnosis of empyema in children: comparative evaluations by culture, polymerase chain reaction, and pneumococcal antigen detection in pleural fluids. Clin Infect Dis. 2006;42(8):1135-40.

3. Saglani S, Harris K, Wallis C, Hartley J. Empyema: the use of broad range $16 \mathrm{~S}$ rDNA PCR for pathogen detection. Arch Dis Child. 2005;90(1):70-3.

4. Mensies SM, Rahman NM, Wrightson JM, Davies HE, Shorten R, Gillespie SH, et al. Blood culture bottle culture of pleural fluid in pleural infection. Thorax. 2011;66(8):658-62.

5. Pernica JM, Moldovan I, Chan F, Slinger R. Real-time polymerase chain reaction for microbiological diagnosis of parapneumonic effusions in Canadian children. Can J Infect Dis Med Microbiol. 2014;25(3):151-4

6. Blaschke AJ. Interpreting Assays for the Detection of Streptococcus pneumoniae. Clin Infect Dis. 2011;52(suppl_4):S331-S7.

7. Marimon JM, Morales M, Cilla G, Vicente D, Perez-Trallero E. Molecular analysis improves pathogen identification and epidemiologic study of pediatric parapneumonic empyema. Pediatr Infect Dis J. 2015;30(4):289-94

8. Vazquez Melendez EL, Farrell JJ, Hujer AM, Lowery KS, Sampath R, Bonomo RA. Culture negative empyema in a critically ill child: an opportunity for rapid molecular diagnostics. BMC Anesthesiol. 2014;14:107.

9. Baudel JL, Tankovic J, Dahoumane R, Carrat F, Galbois A, Ait-Oufella H, et al. Multiplex PCR performed of bronchoalveolar lavage fluid increases pathogen identification rate in critically ill patients with pneumonia: a pilot study. Ann Intensive Care. 2014:4:35.

10. Yoshii Y, Shimizu K, Morozumi M, Chiba N, Ubukata K, Uruga H, et al. Identification of pathogens by comprehensive real-time PCR versus conventional methods in community-acquired pneumonia in Japanese adults. Infect Dis Ther. 2016:48(11-12):782-8.

11. Prasad R, Kumari C, Das BK, Nath G. Nested polymerase chain reaction (PCR) targeting $16 \mathrm{~S}$ rDNA for bacterial identification in empyema. Paediatr Int Child Health. 2014;34(2):125-7.

12. Zampoli M, Kappos A, Wolter N, von Gottberg A, Verwey C, Mamathuba R, et al. Etiology and incidence of pleural empyema in south African children. Pediatr Infect Dis J. 2015;34(12):1305-10.

13. Gollomp K, Rankin SC, White C, Mattei P, Harris MC, Kilpatrick LE, et al. Broad-range bacterial polymerase chain reaction in the microbiologic diagnosis of complicated pneumonia. J Hosp Med. 2012;7(1):8-13.

14. Podbielski A, Herrmann M, Kniehl E, et al. Mikrobiologisch-infektiologische Qualitätsstandard (MiQ). Urban and Fischer Elsevier GmbH: Munich; 2010.

15. Light RW. The Light criteria: the beginning and why they are useful 40 years later. Clin Chest Med. 2013;34(1):21-6.

16. McGraw MD, Robison K, Kupfer O, Brinton JT, Stillwell PC. The use of light's criteria in hospitalized children with a pleural effusion of unknown etiology. Pediatr Pulmonol. 2018;53(8):1101-6.

17. Light RW. Parapneumonic effusions and empyema. Proc Am Thorac Soc. 2006:3(1):75-80.

18. Bhatnagar R, Maskell NA. Treatment of complicated pleural effusions in 2013. Clin Chest Med. 2013;34(1):47-62.

19. Feller-Kopman D, Light R. Pleural disease. N Engl J Med. 2018;378(8):740-51.

20. Menezes-Martins LF, Menezes-Martins JJ, Michaelsen VS, Aguiar BB, Ermel T, Machado DC. Diagnosis of parapneumonic pleural effusion by polymerase chain reaction in children. J Pediatr Surg. 2005;40(7):1106-10.

21. Utine GE, Pinar A, Özçelik U, Şener B, Yalçin E, Doğru D, et al. Pleural fluid PCR method for detection of $<i>$ Staphylococcus aureus, Streptococcus pneumoniae $</ \mathrm{i}>$ and $<\mathrm{i}>$ Haemophilus influenzae $</ \mathrm{i}>$ in pediatric Parapneumonic effusions. Respiration. 2008;75(4):437-42.

22. Krenke K, Sadowy E, Podsiadły E, Hryniewicz W, Demkow U, Kulus M. Etiology of parapneumonic effusion and pleural empyema in children. The role of conventional and molecular microbiological tests. Respir Med. 2016; 116(Supplement C):28-33.

23. El-Sokkary RH, Ramadan RA, El-Shabrawy M, El-Korashi LA, Elhawary A, Embarak S, et al. Community acquired pneumonia among adult patients at an Egyptian university hospital: bacterial etiology, susceptibility profile and evaluation of the response to initial empiric antibiotic therapy. Infect Drug Resist. 2018;11:2141-50. 
24. Johansson N, Vondracek M, Backman-Johansson C, Sköld MC, AnderssonYdsten K, Hedlund J. The bacteriology in adult patients with pneumonia and parapneumonic effusions: increased yield with DNA sequencing method. Eur J Clin Microbiol Infect Dis. 2019:38(2):297-304.

25. Mustafa MIA, Al-Marzooq F, How SH, Kuan YC, Ng TH. The use of multiplex real-time PCR improves the detection of the bacterial etiology of community acquired pneumonia. Trop Biomed. 2011;28(3):531-44

26. Batra P, Mathur P, Misra MC. Clinical characteristics and prognostic factors of patients with Stenotrophomonas maltophilia infections. J Lab Physicians. 2017:9(2):132-5.

27. Yin C, Yang W, Meng J, Lv Y, Wang J, Huang B. Co-infection of Pseudomonas aeruginosa and Stenotrophomonas maltophilia in hospitalised pneumonia patients has a synergic and significant impact on clinical outcomes. Eur J Clin Microbiol Infect Dis. 2017;36:2231-5.

28. Lee MR, Wang HC, Yang CY, Lin CK, Kuo HY, Ko JC, et al. Clinical characteristics and outcomes of patients with pleural infections due to Stenotrophomonas maltophilia at a medical center in Taiwan, 2004-2012. Eur J Clin Microbiol Infect Dis. 2014;33:1143-8.

29. Gollomp K, Rankin SC, White C, Mattei P, Harris MC, Kilpatrick LE, ShefflerCollins S, McGowan KL, Shah SS. Broad-range bacterial polymerase chain reaction in the microbiologic diagnosis of complicated pneumonia. J Hosp Med. 2012;7(1):8-13,

30. Schulte B, Eickmeyer H, Heininger A, Juretzek S, Karrasch M, Denis O, et al. Detection of pneumonia associated pathogens using a prototype multiplexed pneumonia test in hospitalized patients with severe pneumonia. PLoS One. 2014;9(11):e110566.

31. Fernandez-Soto P, Velasco Tirado V, Carranza Rodriguez C, Perez-Arellano JL, Muro A. Long-term frozen storage of urine samples: a trouble to get PCR results in Schistosoma spp. DNA detection? PLoS One. 2013;8(4):e61703.

32. Cushwa WT, Medrano JF. Effects of blood storage time and temperature on DNA yield and quality. Biotechniques. 1993;14(2):204-7.

33. Affolter K, Schumann DM, Tamm M, Jahn K, Siebeneichler A, Junker L, et al. Multiplex PCR on the Bronchoalveolar lavage fluid of Immunocompromised patients. Chest. 2018;154(3):722-5.

34. Dyrhovden R, Nygaard RM, Patel R, Ulvestad E, Kommedal O. The bacterial aetiology of pleural empyema. A descriptive and comparative metagenomic study. Clin Microbiol Infect. 2019;25(8):981-6.

35. Franchetti L, Schumann DM, Tamm M, Jahn K, Stolz D. Efficacy of a multiplex bacterial PCR in identifying pathogens in pleural empyema. Respiration. 2018;95(Abstracts):478-516.

\section{Publisher's Note}

Springer Nature remains neutral with regard to jurisdictional claims in published maps and institutional affiliations.

Ready to submit your research? Choose BMC and benefit from:

- fast, convenient online submission

- thorough peer review by experienced researchers in your field

- rapid publication on acceptance

- support for research data, including large and complex data types

- gold Open Access which fosters wider collaboration and increased citations

- maximum visibility for your research: over $100 \mathrm{M}$ website views per year

At BMC, research is always in progress.

Learn more biomedcentral.com/submissions 